\title{
DO MALE AND FEMALE PLANTS DISPLAY DIFFERENT HAPLOTYPE PATTERNS IN THE MOSS DREPANOCLADUS TRIFARIUS (BRYOPHYTA, AMBLYSTEGIACEAE)?
}

\author{
LARS HEDENÄS ${ }^{1} \&$ IRENE BISANG
}

\begin{abstract}
The moss Drepanocladus trifarius (F. Weber \& D. Mohr) Broth. ex Paris was used as a model species for a first evaluation of whether male and female haplotype patterns based on a combination of the nuclear molecular markers ITS and gpd, and the chloroplast $r p l 16$ are congruent or not. In 23 female and 23 male shoots from specimens sampled in Northern and Central Europe, sex was determined either by the presence of sexual branches or by a recently developed molecular marker. Analysis of molecular variance (AMOVA) showed that a small $(6 \%)$ and almost significant $(\mathrm{p}=0.066)$ fraction of the variation within the data is due to differences between the genders and that the haplotype diversity is higher among females than among males. No significant differences in haplotype variation were found among geographical regions. The near significant differences between females and males, despite low variation in ITS and $r p l 16$, in this first study ever of potential differences in haplotype variation between genders of dioecious mosses suggests that further investigations of more specimens and more variable molecular markers should be performed. Such studies could potentially reveal patterns of relevance to understanding, for example, immigration routes and to pin-point refugial areas of different significance to the respective genders.
\end{abstract}

Key words: Dioecious, Haplotype diversity, Molecular sex marker, Wetland

Lars Hedenäs \& Irene Bisang, Swedish Museum of Natural History, Department of Cryptogamic Botany, Box 50007, SE-104 05 Stockholm, Sweden; e-mail: lars.hedenas@nrm.se \& irene.bisang@nrm.se

\section{INTRODUCTION}

During recent years, molecular methods to determine the sex of individual shoots of dioecious mosses that do not express sex have been found or developed (Bisang et al. 2010; Korpelainen et al. 2008; McDaniel et al. 2007). This has allowed straightforward testing of whether the ratios between expressing males and females are a result of unequal expressing rates or if the expressed sex ratios correspond with the genetic population level sex ratios (Bisang \& Hedenäs 2013; Hedenäs et al. 2010). The possibility to determine the sex of individual shoots of a species also enables us to study the detailed distribution of males and females in populations and in the landscape, and to test for potential niche partitioning of the sexes (Barrett \& Hough 2013; Bisang \& Hedenäs, in prep.). Sexing of non-reproductive shoots circumvents potential difficulties with gender specific expression

\footnotetext{
1 Corresponding author
}

rates. Moreover, it allows examining the genetic structure and potentially differing performances of males and females also in species that rarely produce male and female organs. In other organisms, sex-specific differences in genetic structure and haplotype diversity have been reported, but to the best of our knowledge this question was not yet addressed in bryophytes (e.g., Fénart et al. 2006; Olson \& McCauley 2002; Teske et al. 2012).

If sexual reproduction has been sufficiently rare over longer periods of time, and vegetative reproduction is at the same time efficient enough that the species can colonize a large geographical region, it appears reasonable to assume that males and females could have dispersed from different source populations and along different immigration routes. If they occur in an area that has only been available for colonization since the Pleistocene the available time in terms of the number of sexually produced generations (cf., Hedenäs 2011; Yu et al. 
2003) was most likely too short to blur such patterns. If differences in colonization history exist between the genders, this should therefore be reflected in their respective haplotype patterns.

We use the dioecious wetland moss Drepanocladus trifarius (F. Weber \& D. Mohr) Broth. ex Paris (Hedenäs \& Rosborg 2009) to test this idea based on variation in two nuclear (ITS, $g p d$ ) and one chloroplast ( $r p l 16$ ) molecular markers that are reasonably variable in other pleurocarpous moss species, using both expressing and molecularly sexed shoots. Extant populations of D. trifarius rarely reproduce sexually, as evidenced by the fact that only $4 \%$ of herbarium specimens from Scandinavia and the European Alps bear sporophytes $(\mathrm{n}=224)$ (Bisang et al., 2006; and unpublished data). This is probably a way too high estimate of the sporophyte frequency in nature, considering that specimens with sporophytes are preferentially collected in such species that rarely produce them. The first author, who has a very extensive field experience of this species during more than 20 years, both in Scandinavia and the Alps, has found sporophytes only twice. Further, in an intensively investigated area of $c a 4.2 \times 3.5 \mathrm{~km}$ in western-central Sweden with copious $D$. trifarius occurrences and both sexes present, which was repeatedly visited during several years, not a single sporophyte was detected (Bisang \& Hedenäs, in prep.). Drepanocladus trifarius has no special means of vegetative reproduction. It distributes within a locality by clonal growth and can probably disperse occasionally between localities by fragments attaching to animals or with running water. Drepanocladus trifarius is thus an appropriate model to test whether haplotype diversity and composition differ between the genders and/or among geographical regions.

\section{MATERIAL AND METHODS}

We selected single shoots from 46 specimens of Drepanocladus trifarius, 23 of which had been determined to be male and 23 female (Table 1). The sex was determined either based on expressed sex in the selected shoots or it was molecularly determined in an earlier study (Hedenäs et al. 2010).
Total DNA was extracted using the DNeasy ${ }^{\circledR}$ Plant Mini Kit for DNA isolation from plant tissue (QIAGEN). Double-stranded DNA templates were prepared by polymerase chain reaction (PCR). PCR was performed using Illustra ${ }^{\mathrm{TM}}$ Hot Start Mix RTG (GE Healthcare) in a $25 \mu 1$ reaction volume according to the manufacturer's instructions.

For all molecular markers, the PCR programs given below were initiated by a denaturation step of $5 \mathrm{~min}$ at $95^{\circ} \mathrm{C}$ and were followed by a final extension period of $10 \mathrm{~min}$ at $72^{\circ} \mathrm{C}$. For the internal transcribed spacers 1 and 2 (ITS) the PCR program employed was 40 cycles of $30 \mathrm{sec}$ at $95^{\circ} \mathrm{C}, 30 \mathrm{sec}$ at $52^{\circ} \mathrm{C}$, and $1 \mathrm{~min} 30 \mathrm{sec}$ at $72^{\circ} \mathrm{C}$, with the primers ' $18 \mathrm{SF}$ ' and '26SR' (Rydin et al. 2004). For the gene glyceraldehyde 3-phosphate dehydrogenase $(g p d)$ an initial two degrees touch down of 2 cycles of $40 \mathrm{sec}$ at $95^{\circ} \mathrm{C}, 40 \mathrm{sec}$ at $58-56^{\circ} \mathrm{C}$, and $1 \mathrm{~min}$ at $72^{\circ} \mathrm{C}$ was followed by 40 cycles of $40 \mathrm{sec}$ at $94^{\circ} \mathrm{C}, 40 \mathrm{sec}$ at $54^{\circ} \mathrm{C}$, and $1 \mathrm{~min}$ at $72^{\circ} \mathrm{C}$, using two primer pairs, 'GPD1790F' (Wall 2002) and the newly developed 'GPD-bryo-nestedR' (5'-CRGTCTTCTGTGTGGCTGC-3') for the first portion of the amplified length, and the newly developed internal 'GPD-460F' (5'-GTTCATAGTCCTCATCTTTGGATTGA-3') and 'GPD3050R' (Wall 2002) for the second portion. For $r p l 16,35$ cycles of $30 \mathrm{sec} 95^{\circ}, 30 \mathrm{sec} 58^{\circ}, 1 \mathrm{~min} 30$ sec $72^{\circ}$ were employed, with the forward primer 'F71' (Jordan et al. 1996) and the reverse 'rpl16-antR2' (Hedenäs 2008a).

Amplified fragments were cleaned with a DyeEx ${ }^{\circledR}$ 96 Kit (QIAGEN) using 1 portion Exonuclease I (EXO I) $20 \mu / \mu 1+4$ portions FastAP ${ }^{\mathrm{TM}}$ Thermosensitive Alkaline Phosphatase $1 \mu / \mu 1$ (Fermenta LIFE SCIENCE). For $20 \mu \mathrm{l}$ PCR reaction, $1 \mu \mathrm{l}$ EXO I +4 $\mu 1$ FastAP ${ }^{\text {TM }}$ was used. Cycle sequencing was performed using the ABI BigDye Terminator Kit (Applied Biosystems) according to the instructions on the kit (BDT ver. 2.0 or 3.1 ), and the sequencing products were cleaned using the DyeEx 96 Kit (QIAGEN). The same primers as for the initial PCR were used, or in some cases 'ITS4-bryo' and 'ITS5-bryo' (Stech 1999) were used for ITS (same PCR program as for '18SF' and '26SR'). Sequencing products were resolved on an ABI3100 automated sequencer. Double stranded sequencing was performed.

Nucleotide sequence fragments were edited and assembled for each DNA region using PhyDE® (http:// www.phyde.de/index.html). The assembled sequences were aligned using ClustalX (Thompson et al., 1997), with a subsequent manual adjustment in PhyDE®. Regions of partially incomplete data in the beginning and end of the sequences were identified and excluded 
Table 1. Studied specimens of Drepanocladus trifarius in the following format: Sample No.: Locality, (Date), Collector (No.); Herbarium acronym, (Herbarium registration No.); Haplotype No. (cf. Fig. 1); Sex \{M: male; F: female $\}$; determined from \{(e) expressing shoots, $(\mathrm{m})$ by means of molecular sex marker\}; Geographical region \{NS: N Scandinavia; CS: C Scandinavia; SS: S Scandinavia; SW: Switzerlandand\}; GenBank accession numbers for ITS, gpd, rpl16.

PT11: Switzerland. Canton Graubünden, Trun, 24 July 2001, Wirkungskontr. Moorbiot. Schweiz; Z; 7; F, e; SW; KC601903, KC601857, KC601949. PT12: Switzerland. Canton Graubünden, Trun, 23 June 1988, Wirkungskontr. Moorbiot. Schweiz; Z; 6; M, e; SW; KC601904, KC601858, KC601950. PT16: Sweden. Pite Lappmark, Bockmyran, C.Jonsson; S, B110749; 6; F, e; NS; KC601905, KC601867, KC601951. PT17: Sweden. Jämtland, Åre, I.Bisang \& L.Hedenäs; S, B112892; 6; M, e; CS; KC601906, KC601868, KC601952. PT19: Sweden. Jämtland, Åre, I.Bisang \& L.Hedenäs; S, B112894; 7; M, e; CS; KC601907, KC601869, KC601953. PT20: Sweden. Jämtland, Åre, I.Bisang \& L.Hedenäs; S, B112895; 2; F, e; CS; KC601908, KC601870, KC601954. PT23; Sweden. Härjedalen, Linsell, L.Hedenäs et al.; S, B121274; 5; F, e; CS; KC601909, KC601871, KC601955. PT24: Sweden. Jämtland, Åre, I.Bisang et al.; S, B121967; 6; M, e; CS; KC601910, KC601872, KC601956. PT25: Sweden. Jämtland, Åre, I.Bisang et al.; S, B121968; 2; M, e; CS; KC601911, KC601859, KC601957. PT26: Sweden. Jämtland, Åre, I.Bisang et al.; S, B121969; 6; M, e; CS; KC601912, KC601873, KC601958. PT27: Sweden. Jämtland, Åre, I.Bisang et al.; S, B121970; 6; M, e; CS; KC601913, KC601874, KC601959. PT29: Sweden. Jämtland, Åre, I.Bisang et al.; S, B121911; 2; F, e; CS; KC601914, KC601875, KC601960. PT31: Sweden. Jämtland, Åre, I.Bisang et al.; S, B121913; 4; F, e; CS; KC601915, KC601876, KC601961. PT32: Norway. Nord-Trøndelag, Meråker, L.Hedenäs; S, B121971; 6; F, e; CS; KC601916, KC601860, KC601962. PT35: Sweden. Uppland, Fasterna, K.Hylander 1993; S, B124821; 7; F, m; SS; KC601917, KC601877, KC601963. PT36: Sweden. Härjedalen, Sveg, L.Hedenäs HD89-106; S, B93295; 7; M, m; CS; KC601918, KC601878, KC601964. PT39: Sweden. Härjedalen, Tännäs, L.Hedenäs; S, B121277; 7; M, m; CS; KC601919, KC601861, KC601965. PT40: Sweden. Småland, Källeryd, L.Hedenäs \& A.Kooijman; S, B1116; 7; F, m; SS; KC601920, KC601862, KC601966. PT42: Sweden. Härjedalen, Ljusnedal, L.Hedenäs; S, B121279; 1; F, m; CS; KC601921, KC601879, KC601967. PT43: Sweden. Härjedalen, Tännäs, L.Hedenäs; S, B121278; 8; F, m; CS; KC601922, KC601863, KC601968. PT44: Sweden. Härjedalen, Ljusnedal, L.Hedenäs; S, B121275; 7; M, m; CS; KC601923, KC601880, KC601969. PT46: Sweden. Pite Lappmark, Arjeplog, L.Hedenäs et al.; S, B114435; 7; F, m; NS; KC601924, KC601864, KC601970. PT47: Sweden. Pite Lappmark, Arjeplog, L.Hedenäs et al.; S, B114018; 7; M, m; NS; KC601925, KC601865, KC601971. PT48: Sweden. Pite Lappmark, Arjeplog, L.Hedenäs et al.; S, B114017; 7; M, m; NS; KC601926, KC601881, KC601972. PT52: Sweden. Torne Lappmark, Jukkasjärvi (Vittangi), L.Hedenäs; S, B73400; 6; M, m; NS; KC601927, KC601882, KC601973. PT53: Sweden. Torne Lappmark, Jukkasjärvi, Torneträsk area, L.Hedenäs; S, B73402; 1; F, m; NS; KC601928, KC601883, KC601974. PT54: Sweden. Torne Lappmark, Jukkasjärvi (Vittangi), L.Hedenäs; S, B73436; 7; F, m; NS; KC601929, KC601884, KC601975. PT55: Sweden. Torne Lappmark, Jukkasjärvi, Torneträsk area, L.Hedenäs; S, B42919; 2; M, m; NS; KC601930, KC601885, KC601976. PT59: Sweden. Öland, Böda, K.Hylander; S, B64105; 6; M, m; SS; KC601931, KC601866, KC601977. PT60: Sweden. Jämtland, Frostviken, L.Hedenäs; S, B124833; 4; F, m; CS; KC601932, KC601886, KC601978. PT61: Sweden. Jämtland, Frostviken, L.Hedenäs J88-76; S, B124834; 6; M, m; CS; KC601933, KC601887, KC601979. PT64: Sweden. Jämtland, Alanäs, L.Hedenäs \& A.Kooijman; S, B1417; 6; F, m; CS; KC601934, KC601888, KC601980. PT66: Sweden. Jämtland, Frostviken, L.Hedenäs \& A.Kooijman; S, B1133; 9; F, m; CS; KC601935, KC601889, KC601981. PT70: Sweden. Jämtland, Åre, L.Hedenäs; S, B73973; 4; M, m; CS; KC601936, KC601890, KC601982. PT76: Sweden. Jämtland, Åre, I.Bisang \& L.Hedenäs; S, B112902; 2; F, m; CS; KC601937, KC601891, KC601983. PT77: Sweden. Jämtland, Åre, I.Bisang \& L.Hedenäs; S, B112903; 3; M, m; CS; KC601938, KC601892, KC601984. PT92: Switzerland. Canton Graubünden, Mesocco, N.Schnyder 2002067b; Z; 7; M, m; SW; KC601939, KC601893, KC601985. PT97: Switzerland. Canton Graubünden, Tarasp, 2000, Wirkungskontr. Moorbiot. Schweiz; Z; 1; F, m; SW; KC601940, KC601894, KC601986. PT98: Switzerland. Canton Ticino, Olivone, N.Schnyder 98074; Z; 1; F, m; SW; KC601941, KC601895, KC601987. PT99: Switzerland. Canton Graubünden, Scuol, L.Hedenäs; S, B72142; 6; M, m; SW; KC601942, KC601896, KC601988. PT250: Sweden. Södermanland, Åker, A.Johansson; S, B94540; 6; M, m; SS; KC601943, KC601897, KC601989. PT251: Sweden. Närke, Vintrosa, N.Hakelier; S, B97426; 6; M, m; SS; KC601944, KC601898, KC601990. PT252: Sweden. Jämtland, Åre, I.Bisang et al.; S, B104736; 6; M, m; CS; KC601945, KC601899, KC601991. PT253: Sweden. Jämtland, Ragunda, L.Hedenäs; S, B193537; 6; F, m; CS; KC601946, KC601900, KC601992. PT254: Sweden. Lycksele Lappmark, Stensele, L.Hedenäs; S, B193552; 7; F, m; NS; KC601947, KC601901, KC601993. PT255: Finland. Åland, Eckerö, L.Hedenäs \& I.Bisang; S, B193662; 7; F, m; SS; KC601948, KC601902, KC601994.

from subsequent analyses. The two codable gaps, when coded as present or absent, provided additional evidence to distinguish haplotypes and the analyses were thus performed with the insertions and deletions coded as single informative characters independent of their length. Paralogous ITS haplotypes are rarely encountered in bryophytes (but see Košnar et al. 2012) and the ITS chromatograms generated in this study did not show 'messy' patterns that could suggest paralogy (cf. Shaw et al. 2002). The revealed ITS variation is thus interpreted as being among homologous haplotypes. The sequence alignments used in the analyses are available on request. GenBank accession numbers are listed in Table 1. 
The program TCS was used to evaluate relationships among male and female haplotypes both in an analysis with all specimens together and in analyses of each sex separately (Clement et al. 2000). To investigate the haplotype variation between male and female $D$. trifarius, and among the geographical regions N Scandinavia, C Scandinavia, S Scandinavia, and Switzerland (cf. Table 1) an analysis of molecular variance (AMOVA) was performed with GENALEX 6.41 (Peakall \& Smouse 2006). The null hypothesis in this and the following analysis is that there are no differences in haplotype variation between the sexes or among the studied regions, respectively. Pairwise $\mathrm{Phi}_{\mathrm{PT}}$ (an analogue of $F_{\mathrm{ST}}$, i.e., genetic diversity among populations) was also estimated with GENALEX 6.41, and the same program was used to calculate the effective number of haplotypes and the haplotype diversity for each gender and region.

\section{RESULTS}

The total number of aligned ITS sites in the 46 studied Drepanocladus trifarius specimens, after deletion of regions at the beginnings and ends that were incomplete for some specimens, was 768 , including 1 site with a base substitution and 1 coded indel. For $g p d$ the corresponding values were 1084, with 9 base substitutions and no indels, and for $r p l 16$ 670, with no base substitutions and 1 indel. The number of parsimony informative sites including indels was 0 for ITS. For gpd the corresponding figure was 9 , and for $r p l 161$. For ITS the sequence length was 768, except for PT43 (720), for gpd 1084, and for rpl16 660-670. The
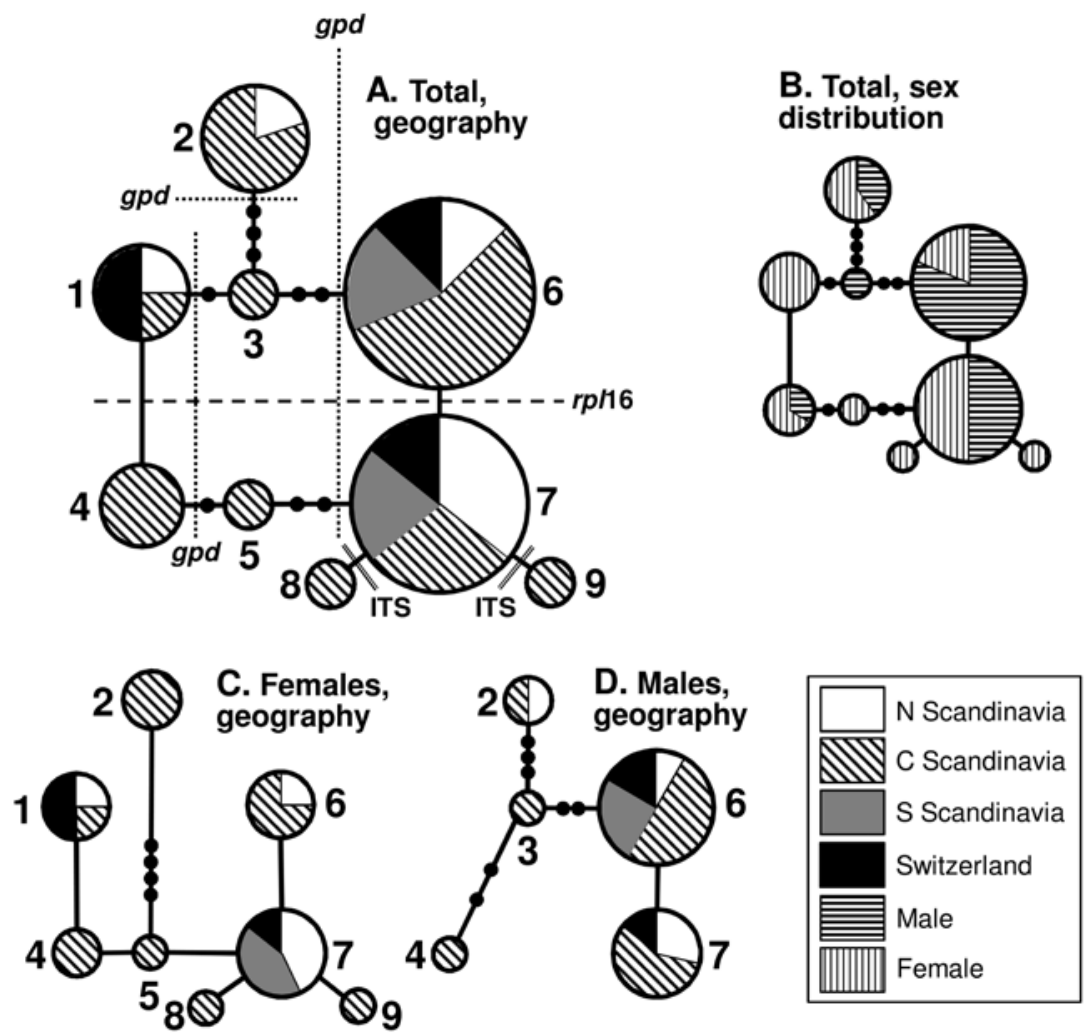

Fig. 1. Haplotype network of 46 specimens (individual shoots) of Drepanocladus trifarius based on the nuclear ITS and gpd, and the plastid rpl16. A - All samples, with the geographical origin of the specimens indicated. Lines with 'ITS', 'gpd' and ' $r p l 16$ ' indicate which molecular marker distinguishes the respective haplotypes. The numbers beside the haplotypes are those given to identify them in the text. B - All samples, with the gender of the specimens indicated. B-D - Haplotype network for the 23 female and 23 male specimens (individual shoots), respectively, with their geographical origins indicated. B \& C are reduced in size compared with A, but within each figure, the sizes of the haplotypes are proportional to their numbers of specimens. 
Table 2. Haplotype diversity information for female and male populations of Drepanocladus trifarius. $\mathrm{n}=$ number of samples; $\mathrm{Na}=$ number of haplotypes; $\mathrm{Ne}=$ number of effective haplotypes; $\mathrm{H}=$ haplotype diversity.

\begin{tabular}{lcccc}
\hline & $\mathrm{n}$ & $\mathrm{Na}$ & $\mathrm{Ne}$ & $\mathrm{H}$ \\
\hline Female & 23 & 8 & 5.454 & 0.817 \\
Male & 23 & 5 & 2.658 & 0.624 \\
\hline
\end{tabular}

variation in ITS and $r p l 16$ is due to the presence of indels.

The statistical parsimony networks based on all markers are shown in Fig. 1. The distributions of samples having different geographical origins and different sexes, among the nine haplotypes, are displayed separately in the total network (Fig. 1A, B), and the geographical distribution is displayed in separate networks based on only female or only male samples (Fig. 1C, D). Haplotypes 6 and 7 (cf. Fig. 1A) include most of the samples, and are distinguished by the indel event in rpl16. No clear pattern of geographical regions or distributions of the genders are evident from visual inspections of the haplotype networks.

The number of haplotypes, effective number of haplotypes, and haplotype diversity are compared for females and males in Table 2. The effective number of haplotypes corresponds to the number of equally frequent haplotypes it would take to achieve a given level of haplotype diversity, and provides a better comparative value than the absolute haplotype number when the relative frequencies of different haplotypes or numbers of sampled specimens differ among categories. The number of effective haplotypes and haplotype diversity are higher for females than males.

For the four geographical regions almost all haplotype variation can be referred to within region variation (Table $3 \mathrm{~A}$ ) and pair-wise $\mathrm{Phi}_{\mathrm{PT}}$ values for geographical regions indicate that no differences in the haplotype patterns exist between these (results not shown). For the females and males there is an almost significant fraction of $6 \%(p=0.066)$ of the variation that is due to between-gender variation (Table 3B).

\section{DISCUSSION}

As far as we are aware, this is the first investigation of a bryophyte species to explore whether female and male plants differ in haplotype and phylogeographic patterns. In flowering plants, DNA haplotype patterns were shown to vary among genders, for example in Silene vulgaris (Moench) Garcke (Olson \& McCauley 2002) or in Beta vulgaris subsp. maritima (L.) Arcang. (e.g., Fénart et al. 2006). The separate assessment of male and females plants was possible thanks to

Table 3. Results of AMOVA to partition haplotype variation (A) within and among the four geographical regions regions $\mathrm{N}$ Scandinavia, C Scandinavia, S Scandinavia, and Switzerland, and (B) within and between the sexes ( $\mathrm{n}=46$; 9 haplotypes (h); $\left.\mathrm{A}: \mathrm{Phi}_{\mathrm{PT}}=0.009, \mathrm{p}=0.405 ; \mathrm{B}: \mathrm{Phi}_{\mathrm{PT}}=0.061, \mathrm{p}=0.066\right)$. P-values are based on 999 permutations. $\mathrm{df}=\mathrm{degrees}$ of freedom, $\mathrm{SS}=$ sums of squares, and $\mathrm{MS}=$ mean squared deviations.

A. GEOGRAPHICAL REGION

\begin{tabular}{lrrrrr}
\hline Source & df & SS & MS & Estimated & $\begin{array}{r}\% \text { of total } \\
\text { variance }\end{array}$ \\
\hline Among regions & 3 & 1.262 & 0.421 & 0.004 & 1 \\
Within regions & 42 & 16.238 & 0.387 & 0.387 & 99 \\
Total & 45 & 17.500 & & 0.390 & 100 \\
\hline
\end{tabular}

B. FEMALE AND MALE

\begin{tabular}{|c|c|c|c|c|c|}
\hline Source & df & SS & MS & $\begin{array}{c}\text { Estimated } \\
\text { variance }\end{array}$ & $\begin{array}{l}\% \text { of total } \\
\text { variation }\end{array}$ \\
\hline Among sexes & 1 & 0.935 & 0.935 & 0.024 & 6 \\
\hline Within sexes & 44 & 16.565 & 0.376 & 0.376 & 94 \\
\hline Total & 45 & 17.500 & & 0.401 & 100 \\
\hline
\end{tabular}


the development of a molecular marker for gender determination in Drepanocladus trifarius, a pleurocarpous moss with rare sexual reproduction (Korpelainen et al. 2008). Our results show that the examination of gender differences in genetic patterns and phylogeography are relatively easy to perform also in bryophytes, provided that sex determination is feasible, either based on sex expression or by genetic markers.

All three studied molecular markers together yielded only twelve variable characters and D. trifarius shows low variation in both ITS and $r p l 16$. The variation in the closely related D. lycopodioides (Brid.) Warnst. is also limited (unpublished data), whereas comparative data for numerous other European pleurocarpous mosses give evidence that significantly greater variation in ITS and rpl16 is common (e.g., Hedderson \& Nowell 2006; Hedenäs 2008b, 2009a, b, 2012). This, in combination with the almost-significant differences between the haplotype patterns of the genders $(p=0.066)$, suggests that the study of additional material, more variable molecular markers or, for example, ISSRs or micro-satellites could potentially reveal stronger differences between the genders. Such an expanded sample should also address the higher level of haplotype diversity that was found among female than male plants (Table 2). In D. trifarius, with males much rarer than females and thus with smaller effective population sizes, males are more likely to have passed bottlenecks during periods of reduced population sizes (cf. Frankham et al. 2002). This could have occurred during the Pleistocene glaciations, when female refugial occurrences were most likely more common than male ones because females are more common, or during other periods when the climate caused reductions in the area of suitable habitat for this species. Since $D$. trifarius rarely produces sporophytes, the imbalance in haplotype diversity between the genders could not be mitigated by sexual reproduction.

Since this is the first study of haplotype differentiation between the genders in a moss, the near-significant difference between female and male haplotype patterns revealed in D. trifarius should be further addressed. This requires an expanded specimen selection, more variable molecular markers, and studies of other generally more variable species. The latter would require that new molecular markers for gender determination are developed.

ACKNOWLEDGMENTS. We thank Keyvan Mirbakhsh for her efficient laboratory work. We appreciate financial support to the molecular work from The Lars Hierta Memorial Foundation (FO2011-0100).

\section{REFERENCES}

BARrett S. C. H. \& Hough J. 2013. Sexual dimorphism in flowering plants. J. Exp. Bot. 64: 67-82.

BISANG I. \& HEDENÄS L. 2013. Males are not shy in the wetland moss Drepanocladus lycopodioides. Int. J. Plant Sci. 174: 733-739.

BISANG I., EHRLÉN J. \& HEDENÄS L. 2006. Reproductive effort and costs of reproduction do not explain female-biased sex ratios in the moss Pseudocalliergon trifarium (Amblystegiaceae). Amer. J. Bot. 93: 1313-1319.

BisAng I., KoRPELAINEN H. \& HedENÄS L. 2010. Can the sexspecific molecular marker of Drepanocladus trifarius uncover gender in related species? J. Bryol. 32: 305-308.

Clement M., Posada D. \& Crandall K. A. 2000. TCS: a computer program to estimate gene genealogies. Molec. Ecol. 9: 1657-1659.

FÉnARt S., Touzet P., ARnaud J.-F. \& Cuguen J. 2006. Emergence of gynodioecy in wild beet (Beta vulgaris ssp. maritima L.): a genealogical approach using chloroplastic nucleotide sequences. Proc. R. Soc. London, Ser. B 273: 1391-1398.

Frankham R., Ballou J. D. \& BRiscoe D. A. 2002. Introduction to conservation genetics. Cambridge University Press, Cambridge.

Hedderson T. A. \& Nowell T. L. 2006. Phylogeography of Homalothecium sericeum (Hedw.) Br. Eur.; toward a reconstruction of glacial survival and postglacial migration. J. Bryol. 28: 283-292.

HEDENÄS L. 2008a. Molecular variation and speciation in $A n-$ titrichia curtipendula s. 1. (Leucodontaceae, Bryophyta). Bot. J. Linn. Soc. 156: 341-354.

HedenÄs L. 2008b. Molecular variation in Drepanocladus aduncus s.1. does not support recognition of more than one species in Europe. J. Bryol. 30: 108-120.

HEDENÄS L. 2009a. Haplotype variation of relevance to global and European phylogeography in Sarmentypnum exannulatum (Bryophyta: Calliergonaceae). J. Bryol. 31: $145-158$. 
HEDENÄS L. 2009b. Relationships among Arctic and non-Arctic haplotypes of the moss species Scorpidium cossonii and Scorpidium scorpioides (Calliergonaceae). Plant Syst. Evol. 277: 217-231.

HEDENÄS L. 2011. Incongruence among morphological species circumscriptions and two molecular data sets in Sarmentypnum (Bryophyta: Calliergonaceae). Taxon 60: 1596-1606.

HEDENÄS L. 2012. Global phylogeography in Sanionia uncinata (Amblystegiaceae, Bryophyta). Bot. J. Linn. Soc. 168: $19-42$.

HEDENÄS L. \& RosbORG C. ['2008'] 2009. Pseudocalliergon is nested within Drepanocladus (Bryophyta: Amblystegiaceae). Lindbergia 33: 67-74.

Hedenäs L., Bisang I., Korpelainen H. \& Cronholm B. 2010. The true sex ratio in European Pseudocalliergon trifarium (Bryophyta: Amblystegiaceae) revealed by a novel molecular approach. Biol. J. Linn. Soc. 100: 132-140.

Jordan W. C., Courtney M. W. \& Neigel J. E. 1996. Low levels of infraspecific genetic variation at a rapidly evolving chloroplast DNA locus in North American Duckweeds (Lemnaceae). Amer. J. Bot. 83: 430-439.

Korpelainen H., Bisang I., Hedenäs L. \& Kolehmainen J. 2008. The first sex-specific molecular marker discovered in the moss Pseudocalliergon trifarium. J. Hered. 99: $581-587$.

KoŠnar J., Herbstová M., KolÁŘ F., Koutecký P. \& KUČERA J. 2012. A case of intragenomic ITS variation in bryophytes: Assessment of gene flow and role of plyploidy in the origin of European taxa of the Tortula muralis (Musci: Pottiaceae) complex. Taxon 61: 709-720.

MCDaniel S. F., Willis H. J. \& ShaW A. J. 2007. A linkage map reveals a complex basis for segregation distortion in an interpopulation cross in the moss Ceratodon purpureus. Genetics 176: 2489-2500.
Olson M. S. \& MCCAULEY D. E. 2002. Mitochondrial DNA diversity, population structure, and gender association in the gynodioecious plant Silene vulgaris. Evolution 56: 253-262.

Peakall R. \& SMouse P. E. 2006. GENALEX 6: genetic analysis in Excel. Population genetic software for teching and research. Mol. Ecol. Notes 6: 288-295.

Rydin C., Pedersen K. R. \& Friss E. M. 2004. On the evolutionary history of Ephedra: Cretaceous fossils and extant molecules. Proc. Natl. Acad. Sci. 101: 16571-16576.

ShaW A. J., MCDANiel S. F., Werner O. \& Ros R. M. 2002. New frontiers in bryology and lichenology. Phylogeography and phylodemography. Bryologist 105: 373-383.

STECH M. 1999. Molekulare Systematik haplolepider Laubmoose (Dicranaceae, Bryopsida). PhD Thesis. Freie Universität Berlin, Berlin.

TeSKe P., PAPAdOPOUlos I., BARKER N. \& MCQUAID C. 2012. Mitochondrial DNA paradox: sex-specific genetic structure in a marine mussel - despite maternal inheritance and passive dispersal. BMC Genetics 13(45): 1-6.

Thompson J. D., Gibson T. J., Plewniak F., JeAnMougin F. \& HigGins D. G. 1997. The ClustalX windows interface: flexible strategies for multiple sequence alignment aided by quality analysis tools. Nucleic Acids Res. 24: 48764882 .

WALL D. P. 2002. Use of the nuclear gene glyceraldehyde 3-phosphate dehydrogenase for phylogeny reconstruction of recently diverged lineages in Mitthyridium (Musci: Calymperaceae). Molec. Phylog. Evol. 25: 10-26.

Yu Z., VitT D. H., CAMPBELl, I. D. \& APPS M. J. 2003. Understanding Holocene peat accumulation pattern of continental fens in western Canada. Can. J. Bot. 81: 267-282.

\section{Received 13 February 2013}

